\title{
POTRET LANSKAP HARMONI DALAM PROSES PROPAGASI SUFISME DI WARUNG KOPI YOGYAKARTA
}

\author{
Aflahal Misbah \\ Pascasarjana UIN Sunan Kalijaga Yogyakarta \\ aflahalmisbah@gmail.com \\ Artikel diterima 30 April, diseleksi 23 Mei, dan disetujui 25 Juni 2018
}

\begin{abstract}
Given the thesis that Sufism is regarded as alternative medium to construct a society that is friendly, tolerant, and appreciating diversity, this paper reviews how accurate this thesis by looking at new phenomena of the propagation of Sufism taking place in coffees. Some main points figured out in this study are: how is the acceptance of the society of/in coffees toward Sufism. To answer this question, the author collected any supporting data from the field with as natural as possible setting. The author's everyday visit is one of ways to find the natural situation in the field. The final result indicates that together with the continuing propagation of Sufism in coffees, there are interesting landscapes demonstrated by the society of coffees. Acceptance between followers (jama'a), coffee drinkers, and visitors, indicates their ways to treat diversity and differences. Each of them does activities in one room, without being bothered each other. Several visitors and coffee drinkers -regardless their religious organisation affiliation outside the coffeeseven present high respect, such as joining the standing (mahall al-qiyam) when performing ritual process of Mawlid (the birth of the Prophet). This circumstance clearly affirms the above thesis.
\end{abstract}

Keywords: Sufisme, Propagation, Diversity, Harmony, Coffees.

\section{PENDAHULUAN}

Sufisme (tasawuf) sebagai salah satu disiplin keilmuan Islam, kini semakin menjadi tumpuan banyak

\begin{abstract}
Abstrak
Berangkat dari tesis bahwa sufisme dianggap sebagai media alternatif untuk membangun masyarakat yang ramah, toleran, dan menghargai keragaman, tulisan ini berusaha mencoba melihat kembali bagaimana akurasi tesis ini dengan meneropong fenomena baru tentang propagasi sufisme yang berlangsung di warung kopi. Poin utama yang ingin dibidik dalam kajian ini adalah bagaimana potret akseptasi masyarakat (di) warung kopi terhadap propagasi sufisme? Untuk menjawab hal ini, penulis mengumpulkan berbagai data pendukung di lapangan dengan setting senatural mungkin. Kunjungan penulis setiap harinya ke warung kopi tersebut merupakan salah satu cara untuk mendapat situasi yang natural di lapangan. Hasil akhir menunjukkan bahwa bersamaan dengan berlangsungnya propagasi sufisme di warung kopi, ada lanskap menarik yang ditampilkan oleh masyarakat warung kopi. Akseptasi di antara pengikut (jama'ah), pengopi, dan pengunjung memberi gambaran bagaimana cara mereka menyikapi keragaman dan perbedaan. Masing-masing melakukan aktivitas dalam satu ruang tanpa ada yang merasa terganggu satu sama lainnya. Beberapa pengunjung dan pengopi -terlepas dari afiliasi organisasi keagamaannya di luar warung kopi-, bahkan memberikan penghormatan yang tinggi, seperti; ikut berdiri (mahal al-qiyam) ketika proses ritual penghormatan dalam sesi Maulid Nabi. Situasi ini jelas memberi afirmasi terhadap tesis di atas.
\end{abstract}

Kata Kunci: Sufisme, Propagasi, Diversitas, Harmoni, Warung Kopi.

kalangan setelah munculnya anggapan dan pembuktian langsung terkait relasi sufisme dengan formasi sosial moral masyarakat muslim, terutama di Indonesia. Heck (2006), Rabasa, Benard, 
Schwartz, Sickle (2007, pp. 73-74), Said Aqil (2013), Bano, Sohail, Hussain (2015) semuanya sepakat atas anggapan sufisme yang bisa dijadikan titik pijak untuk memformulasikan masyarakat yang toleran dan moderat.

Kendati wajah sufisme kerap dianggap toleran, ini tidak sepenuhnya diterima oleh Woodward, Umar, Rohmaniyah dan Yahya (2013). Menurut mereka, meskipun sufisme banyak berisi ajaran cinta kasih dan kedamaian, bukan berarti ini bisa dijadikan parameter untuk menilai bahwa sufisme bisa menimbulkan sikap toleran. Dalam prakteknya, kasuskasus kekerasan yang terjadi sebagian dilakukan oleh para sufi, dan sebagianlain dilakukan oleh kelompok salafi. Dengan kata lain, masih dalam pandangan mereka, tidak ada hubungannya antara doktrin teologis dengan praktek yang terjadi di lapangan.

Nampaknya, pandangan dari Woodward, dkk (2013) masih kurang kuat untuk meruntuhkan tesis relasi sufisme dengan formasi sosial moral di masyarakat. Beberapa studi terbaru tentang diseminasi sufisme banyak memberikan peneguhan atas hubungan signifikan tersebut. Zamhari (2010) dan Makhasin (2015) misalnya, meski keduanya berbeda titik tekan dan subjek penelitiannya, namun hasil penelitian dari keduanya -baik secara langsung atau tidak- semakin memperkuat tesis tersebut. Fokus Zamhari pada ritual, ajaran dan perdebatan teologis antara Majlis Zikir di Jawa Timur, kelompok tarekat, dan Salafi, memberi konfirmasi pentingnya penyebaran sufisme untuk membangun masyarakat yang cinta damai dan harmoni (Zamhari, 2010, pp. 192-206). Lebih tegas, Makhasin (2015) melalui studi kelompok NaqshabandiHaqqani di Indonesia, mengatakan bahwa sufisme masih kuat sekali pengaruhnya terhadap pembentukan kesalehan muslim dan moralitas publik. Gerakan sufisme
Naqshabandi-Haqqani menurutnya telah membentuk cosmopolitan pietism (kesalehan kosmopolitan). Kesalehan ini bisa menjadi fondasi kebudayaan yang kuat untuk membangun masyarakat yang demokratis di Indonesia.

Beranjak dari uraian di atas, tulisan ini berupaya melihat kembali bagaimana akurasi tesis mengenai sufisme itu. Penulis mencoba menempatkan ulang tesis tersebut sebagai hipotesis agar mampu melihat fenomena diseminasi sufisme dan pengaruhnya secara lebih jernih. Dalam tulisan ini, penulis akan mendeskripsikan fenomena baru tentang diseminasi sufisme yang terjadi di Warung Kopi -yang belum terpotret oleh beberapa studi sufisme sebelumnya (Beck, 2014; Howell, 2010; Ichwan, 2016; Laffan, 2007; Makhasin, 2015, 2016; Mas'ud, 2011; Sarr, 2016; Zamhari, 2010, 2013; Zamhari \& Howell, 2012). Titik tekan dalam studi ini lebih diarahkan pada penangkapan lanskap akseptasi masyarakat di warung kopi pada saat berlangsungnya propagasi tersebut, di samping tetap memberikan gambaran -yang tidak sepenuhnya detail- terkait bentuk dan karakteristik doktrin sufisme yang di dakwahkan. Penangkapan lanskap ini sangat penting untuk melihat bagaimana implikasi langsung dari sufisme di masyarakat.

\section{METODE}

Data yang didapat dalam tulisan ini berasal dari hasil pengamatan mulai awal Januari 2018 dan masih berlangsung hingga tulisan ini dibuat, tepatnya di bulan April 2018. Foto-foto, wawancara informal, rekaman video, dan beberapa bukti pendukung lain yang penulis kumpulkan setiap hari di warung kopi, akan menjadi penopang dalam menggambarkan lanskap akseptasi masyarakat atas sufisme. Ini merupakan penelitian awal dan sifatnya masih deskriptif-sistematis karena hanya akan 
menggambarkan lanskap awal akseptasi yang ditampilkan oleh masyarakat di warung kopi.

Pemakaian kata warung kopi di sini merujuk pada istilah keseharian yang sering diucapkan oleh para pengunjung dan pengopi, meskipun tempat yang menjadi subjek pembahasan dalam tulisan ini secara resmi menggunakan kata kafe. Meskipun masih berupa penelitian awal, pemilihan objek studi di warung kopi ini mempunyai beberapa argumen dasar yang kontributif-akademis, pertama, studi ini memandang bahwa fenomena perkembangan diseminasi sufisme di Indonesia semakin variatif dan inovatif dalam memanfaatkan ruang-ruang baru. Di sini, warung kopi menjadi salah satu parameter penting untuk melihat fenomena tersebut. Fenomena ini merupakan salah satu bagian dari apa yang disebut oleh akademisi dengan 'kebangkitan Islam' (Islamic revival) (baca Bruinessen, 2009; Howell, 2001). Kedua, melalui studi ini, pemetaan terhadap bentuk dan karakteristik dari doktrin dan praktek sufisme yang sedang berkembang dan berpengaruh di masyarakat Indonesia kontemporer dapat dilakukan. Ini didasari atas pemahaman bahwa tidak semua bentuk sufisme mampu mewujud dalam berbagai ruang, beberapa ada yang terbatas dalam ruang yang 'disucikan' atau 'disakralkan'. Ketiga, dalam sejarah masyarakat muslim, warung kopi mempunyai diskursus yang menarik dan unik di masyarakat seperti yang akan dipaparkan di salah satu sub-bab berikut nanti. Keempat dan terakhir, sesuai dengan poin utama yang menjadi arah tulisan ini, warung kopi menjadi salah satu ruang yang sangat representatif untuk melihat ulang tesis tentang relasi dan pengaruh sufisme dalam pembentukan formasi sosial moral di masyarakat. Pandangan ini berasal dari realitas masyarakat di warung kopi itu sendiri yang sangat plural sekali, baik dari aspek agama, identitas, kelas, dan latar belakang sosial lainnya.

\section{HASIL DAN PEMBAHASAN}

\section{Proliferasi Sufisme: Membaca Ruang- Ruang Propagasi}

Islam dan sufisme di Indonesia, keduanya seperti dua sisi mata uang yang tidak bisa dipisahkan, demikian asumsi yang sudah lazim hingga sekarang. Sebagian sarjana, seperti Jones (1961), memberikan afirmasi mengenai hal ini, sufismedipandangsebagaielemenpenting dalam penyebaran dan perkembangan Islam di Indonesia. Meskipun hanya salah satu dari dimensi keberhasilan islamisasi di Indonesia, karena masih banyak elemen dan pendukung lainnya (Johns, 1995, pp. 182-183), bagaimanapun, peran sufisme, seperti diasumsikan Howell (2001), tetap tidak bisa diabaikan hingga sekarang dalam lanskap sosial dan politik masyarakat Indonesia.

Menjelang Abad 21, 'islamic revival' atau kebangkitan Islam sering menjadi label yang menarik di kalangan peneliti untuk menangkap fenomena agama di Indonesia, termasuk sufisme di dalamnya. Dalam konteks ini, sufisme terus berkembang dan menjangkau berbagai sektor ruang publik yang tidak dapat diprediksi sebelumnya. Sufismejuga tidak lagi identik dengan masyarakat rural dan tidak berpendidikan sebagai pengikutnya. Masyarakat urban, bahkan kaum salafi modern -seperti Hamka dan Arifin Ilham-, banyak yang semakin tertarik untuk mempelajari dan mempraktekkan sufisme, baik yang berafiliasi kepada tarekat maupun kepada bentuk-bentuk baru yang mengakomodasi sufisme. Kondisi ini menimbulkan asumsi yang semakin memperlemah kategorisasi masyarakat muslim Indonesia antara tradisional dan modern (lihat Bruinessen, 1994, 2009, Howell, 2001, 2007, 2010). Corak kategorisasi tersebut sudah kian tergerus bersamaan dengan semakin banyaknya fenomena proliferasi sufisme, karena dalam sufisme terdapat paham yang identik dengan doktrin dalam 
salafisme, demikian sebaliknya. Meskipun sebenarnya, kategorisasi itu juga masih terus relevan sepanjang perdebatan di antara mereka masih terjadi, seperti yang ditangkap oleh Laffan (2007) melalui studinya tentang majalah Salafy dan Sufi.

Terlepas dari kategorisasi tersebut, ada elemen penting yang patut diperhatikan secara serius bersamaan dengan giatnya proliferasi sufisme di masyarakat, yaitu, ruang. Ruang merupakan aspek penting untuk melihat perkembangan proliferasi sufisme yang terjadi di era kontemporer, di samping untuk meneropong lebih jauh bagaimana kontribusi sufisme terhadap formasi sosial moral di masyarakat, atau disebut Makhasin (2015, p. 337) dengan pembentukan 'kesalehan kosmopolitan' (cosmopolitan pietism). Dengan kata lain, dimensi 'ruang' mampu dijadikan titik pijak untuk membangun atau meneguhkan tesis relasi sufisme dengan formasi sosial moral di masyarakat.

Dimensi ruang bukanlah hal baru dalam studi sufisme di Indonesia, terutama yang membangun proyek penelitiannya berbasis data empirik. Kajian dari Yon Machmudi (2006), Arif Zamhari (2010, 2013), dan Luthfi Makhasin (2015, 2016) bisa dijadikan sebagai alat bantu untuk melihat dimensi ruang ini, meskipun fokus mereka bukan pada ruang itu sendiri. Untuk lebih mudah melihat apa ruang yang dimaksud di sini, penulis mencoba membuat klasifikasi tentang ruang itu sendiri. Berdasar pada kajian dari tiga peneliti itu, ada dua ruang penting yang patut diperhatikan, yaitu; wadah atau institusi dan arena atau medan. Yang pertama merupakan ruang yang mengakomodasi doktrin dan praktek sufisme, sedangkan yang kedua merupakan ruang yang menjadi tempat di mana sufisme mampu terdiseminasikan. Dalam konteks yang kedua, selain sebagai tempat propagasi sufisme, ruang tersebut juga menjadi media untuk mendiseminasikan sufisme.
Sebenarnya, dua ruang ini, sebelum kajian dari ketiga peneliti tersebut, Bruinessen dan Howell sudah banyak memberikan gambaran tentang bagaimana sufisme mampu beradaptasi denganarusmodernitasdanmenampilkan sifatnya yang lunak dan fleksibel; mampu mewujud dan bertransformasi ke dalam bentuk-bentuk baru, baik dalam bentuk organisasi tradisionalnya -tarekatdisertai dengan beberapa perubahan penting di dalamnya, atau mewujud dalam bentuk yang lebih modern, seperti Kajian Klub Agama, Kursus Intensif, dan Workshop Spiritual. Beberapa bentuk ini pada umumnya -melampaui objek dakwah dari bentuk-bentuk lamamampu menjangkau masyarakat urban, dari kelas menengah hingga elit-elit sosial, mahasiswa, intelektual, seniman, anak muda, baik laki-laki maupun perempuan, baik dari kelompok modernis maupun tradisional. Ruang yang menjadi media untuk menyebarkan sufisme juga mampu mengelola -bukan hanya masjid dan pesantren- ruang-ruang yang terbilang baru seperti universitas dan media cetak (Bruinessen, 1994; Howell, 2001). Dalam perkembangannya, ada bentuk-bentuk baru -yang semakin menguatkan tulisan mereka tentang ruang-ruang proliferasi sufisme- yang terus bermunculan dan belum terpotret dalam uraian mereka berdua.

Kajian Yon Machmudi (2006) tentang Jemaah Tarbiyah dan PKS (Partai Keadilan Sejahtera) memberikan gambaran menarik bagaimana sufisme mampu menempati gerakan kelompok reformis modern dengan gaya baru (sintesis antara gerakan reformasi Islam purifikatif dan akomodatif) dan partai politik. Ruang jangkauannya terbilang cukup masif di masyarakat, khususnya di lingkungan pendidikan tinggi atau universitas dan politik. Label 'santri global' yang dipakai oleh Machmudi untuk menyebut objek kajiannya menunjukkan bagaimana luasnya 
ruang cakupan dakwah yang ditempati kelompok tersebut untuk menyebarkan -salah satunya- doktrin sufisme yang mempengaruhinya.

Selanjutnya, studi Zamhari (2010, 2013) tentang tiga kelompok 'Majlis Zikir dan Shalawat', menunjukkan bentuk sufisme yang mampu meresap dan menyatu dengan institusi-institusi baru, yaitu 'Majlis Zikir dan Shawalat', baik dalam bentuk institusi formal maupun informal. Cakupan diseminasinya terbilang sangat luas di Indonesia dan meliputi berbagai kalangan yang menjadi objek dakwahnya, dari kaum rural hingga kaum urban, dari berbagai kategori sosial seperti orang ruwet, Islam KTP, sampah masyarakat, anak muda, bahkan nonmuslim. Ruang yang digunakan sebagai medianya pun terbilang cukup variatif, masing-masing 'Majlis Zikir dan Shalawat' menampilkan cara yang berbeda dalam pemanfaatan ruang tergantung objek dakwahnya, seperti menempati ruang kultural dengan cara memanfaatkan seni yang sudah ada, seperti jaranan, reog, orkes melayu, leang-leong, dan ruwatan. Selain itu, ada pula yang memanfaatkan pemakaman umum sebagai ruang dan media propagasi sufismenya.

Lebih jauh, kerangka teoritik social movement yang digunakan oleh Makhasin $(2015,2016)$ untuk menganalisa kelompok Naqshabandi-Haqqani semakin banyak memberikan gambaran terkait begitu inovatifnya pemanfaatan ruang yang digunakan. Meskipun bentuk yang mengakomodasi sufisme adalah tarekat, namun bentuknya sudah mengadopsi karakteristik lembaga modern dan menjadi institusi formal. Gerakan sosial kelompok tersebut terbilang sangat luas jangkauannya karena mampu menarik berbagai pengikut dari berbagai kalangan, dan mampu memanfaatkan banyak ruang sebagai media propagasi doktrin dan praktek sufismenya, seperti media cetak, new media, khutbah jum'ah, hadrah dan tari sufi, televisi, dzikir akbar dan perayaan maulid, hingga konferensi dan seminar ilmiah.

Banyak sekali ruang yang dapat di eksplorasi untuk menunjukkan proliferasi sufisme yang semakin masif di masyarakat, di samping melihat secara langsung bagaimana relasi sufisme dengan formasi sosial moral. Beberapa yang sudah disebut di atas serta beberapa penelitian lainnya yang tidak bisa disebutkan semuanya, sepanjang penelusuran penulis, secara keseluruhan belum ada yang menyentuh dan mengkaji secara khusus bagaimana praktek propagasi sufisme yang saat ini juga mampu menyentuh warung kopi. Ruang ini penting untuk melihat dampak langsung dari sufisme terhadap pembentukan formasi moral di masyarakat. Hal ini dikarenakan karakter masyarakat di warung kopi itu sendiri yang sangat plural.

\section{Warung Kopi: Ruang dan Media Propagasi Sufisme}

Kopi, sufi dan sufisme merupakan beberapa elemen penting dalam sejarah Islam. Awal mula munculnya teknologi pembuatan kopi, dalam beberapa literatur, tidak bisa terlepas dari campur tangan para sufi. Bagi para sufi, kopi bukan hanya komoditas pasar dan penambah stamina untuk bekerja. Selain dipercaya sebagai obat untuk berbagai penyakit (lebih lengkap baca Islam et al., 2016)"id":"ITEM1 ", "issue": ${ }^{\prime \prime}$ ", "issued": $\{$ "dateparts": [ ["2016"] ] \}, "page":" 1 7","title":"Coffee: A Health Fuel-blot Popular Drinking","'type":"article-journa 1 ", "volume":" 8 "\},"prefix":"lebih lengkap baca", "uris": ["http://www.mendeley. com/documents/?uuid=e41ea280-b6543199-96a0-1dfd6b55305f"]\}],"mendeley ":\{“formattedCitation":" (lebih lengkap baca Islam et al., 2016, kopi juga berfungsi sebagai alat bantu untuk beribadah dan 
mempraktekkan doktrin dan ajaran dalam Islam, sufisme khususnya, seperti berzikir sepanjang malam (lihat Topik, 2009, pp. 87-91). Kontinuitas relasi ini, bisa dikatakan terus berlangsung hingga sekarang. Di Indonesia, kopi juga menjadi perhatian serius oleh para sufi seperti Syekh Ihsan Jampes, hingga akhirnya ditulis menjadi sebuah diskursus penting (baca Ni'am, 2015).

Kendati demikian, bukan berarti posisi kopi dalam masyarakat muslim adalah stabil dan aman. Perdebatan tentang kopi sudah berlangsung cukup lama, seperti yang terjadi di Arab Saudi yang dimotori oleh kelompok Wahhabi. Kopi dinilai sesuatu yang tidak ada dalam al-Qur'an, dan karenanya harus dilarang. Perdebatan ini bahkan meluas hingga ke tempat penjualan kopi itu sendiri, warung kopi. Di Turki, Sultan Ottoman Murad IV pernah mengeluarkan dekrit tentang larangan bagi warung kopi, dan menghukum pemiliknya dengan cara dimasukkan dalam tas dan dibuang ke Bosporus (lihat Topik, 2009, pp. 88-91).

Karakteristik yang terbuka dan bebas merupakan salah satu faktor dari semua itu. Di warung kopi, publik bebas dan mampu membentuk opini tentang berbagai persoalan yang sedang berkembang di masyarakat. Sirkulasi opini mampu beredar dengan cepat dan dapat diterima bebas oleh berbagai kalangan -kecuali di Eropa pada periode awal datangnya kopi yang mana warung kopi hanya dapat diakses oleh kalangan tertentu (lihat Fotić, 2011, pp. 91-93). Karakteristik ini terus bertahan dari masa ke masa, dari generasi ke generasi, meskipun tidak selalu stabil. Tidak mengejutkan apabila banyak tokoh yang memanfaatkan hal ini untuk mengekspresikan kepentingannya, dari mulai politik hingga agama. Tokoh penting Fethullah Gullen dikabarkan pernah melakukan dakwah di warung kopi (lihat Huda, 2017, p. 47).
Di Yogyakarta, karakteristik warung kopi tidak jauh berbeda dengan apa yang terjadi dalam sejarah. Keterbukaan untuk semua kalangan serta harga yang relatif dapat dijangkau oleh semua kelas sosial -meskipun tidak semuanya- bisa di jumpai di berbagai sudut kota, terutama di sekitaran universitas-universitas yang ada di Yogyakarta.

Letak warung kopi di lingkungan kampus memang bukan hal baru. Pada pertengahan abad 20, warung-warung kopi membanjiri salah satu negara bagian Amerika, Massachusetts. Lokasinya pada umumnya berada di lingkungan kampus. Keberadaan warung kopi ini umumnya banyak dimanfaatkan untuk menggerakkan aktivitas intelektual (lihat Stern, 1969). Mirip dengan apa yang terjadi di Massachusetts, warung kopi di sekitaran kampus Yogyakarta juga banyak digunakan oleh para mahasiswa dan dosen untuk berkumpul dan menjalankan aktivitasnya. Dalam kondisi ini, tidak dapat dinafikan adanya diskusi-diskusi kecil hingga besar yang dilakukan oleh mereka, meski beberapa di antaranya ada yang melakukan berbagai aktivitas lain seperti bermain gitar, bernyanyi, main catur, dan sebagainya.

Diskusi akademik di warung kopi memang bukan hal aneh ketika berada di Yogyakarta, ini mengingat lokasinya yang tidak jauh dari jangkauan para mahasiswa dan dosen. Namun, Yogyakarta memiliki warna lain dalam hal ini. Salah satu warung kopi di Yogyakarta yang berada di Jalan Sorowajan, tidak jauh dari UIN Sunan Kalijaga, menawarkan ruang yang menarik bagi semua kalangan, khususnya mahasiswa dan dosen. Bukan hanya sebagai ruang untuk membentuk opini yang berkembang di masyarakat, melainkan juga memberikan ruang bagi para sufi untuk berdakwah. Kegiatan rutin yang bertema "Senandung Cinta" merupakan acara yang didukung secara resmi oleh pemilik warung kopi. Situasi ini tentu berbeda dengan apa yang terjadi

\begin{tabular}{l|l} 
Jurnal Multikultural \& Multireligius Vol. 17 & No. 1
\end{tabular} 
di Turki, yang mana Fethulleh Gulen melakukan dakwahnya sendiri dan tidak ada dukungan resmi dari pemilik warung kopinya (lihat seksama Huda, 2017, p. 47).

Melihat situasi ini, warung kopi kini semakin variatif fungsinya, bukan hanya sebagai ruang diskusi para intelektual muda, melainkan juga sebagai ruang sekaligus media bagi para sufi untuk menyebarkan doktrin dan ajarannya. Satu sisi, ini bisa dikatakan sebagai fenomena baru, khususnya di Yogyakarta, dalam sejarah warung kopi di masyarakat muslim. Terlebih kegiatan dakwah ini juga didukung secara resmi oleh pemilik warung kopinya. Di sisi lain, ada perkembangan relasi antara sufi dan kopi, yang mana para sufi bukan hanya memanfaatkan kopi sebagai media bantu praktek spiritual, melainkan juga memanfaatkan ruang penjualan kopi sebagai media berdakwah. Terlepas dari adanya campur tangan pemilik warung, yang jelas, warung kopi kini menjadi salah satu ruang dan media propagasi sufisme.

\section{Senandung Cinta: Propagasi Sufisme di Warung Kopi}

Senandung Cinta merupakan tema dari pengajian sufi yang berlangsung setiap Rabu malam pukul 19.30-22.00 WIB di Kafe Basa Basi (selanjutnya ditulis "warung kopi" merujuk pada istilah keseharian yang dipakai oleh para pengunjung dan pengopi). Acara ini merupakan bagian dari kegiatan rutin Kuswaidi Syafi'ie (selanjutnya ditulis "Cak Kus") setiap Minggunya selama di Yogyakarta selain beberapa acara rutin lainnya, ditambah dua kegiatan selapanan yang diselenggarakan secara rutin setiap Malam Minggu Wage di Pesantren Maulana Rumi dan Malam Minggu Pon di Joglo Habib Usman. Secara kelembagaan, kegiatan ini masuk dalam rangkaian dakwah "Majelis
Sholawat \& Tasawuf" yang dipimpin oleh Cak Kus sendiri, penyair dan pengasuh Pondok Pesantren Maulana Rumi di Bantul, Yogyakarta (lihat Gambar. 1).

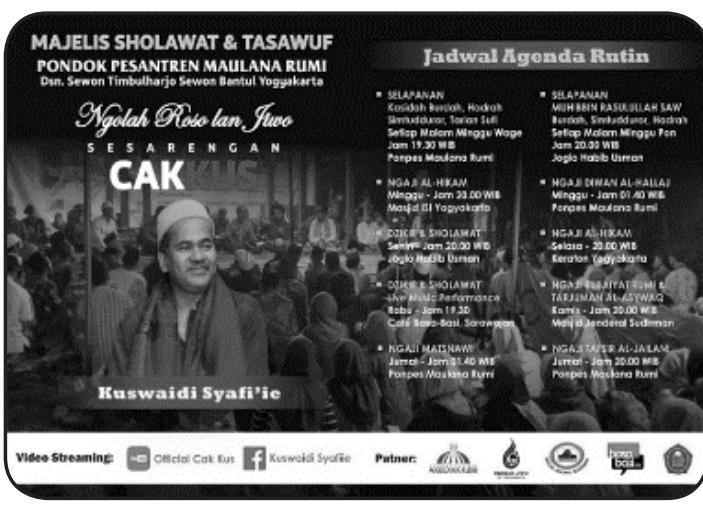

Gambar 1

Jika melihat gambar atau pamflet di atas, tema yang menjadi kegiatan dakwah sufisme di warung kopi adalah "Dzikir dan Sholawat". Namun secara lebih spesifik, tema yang digunakan pada saat berlangsungnya acara adalah "Senandung Cinta: Qasidah dan Kajian Burdah Imam Busyiri, Ngolah Roso lan Jiwo Bersama Kuswaidie Syafi'ie (Cak Kus)". Ini bisa dilihat pada Gambar. 2 (pamflet) dan Gambar. 3 (foto saat acara berlangsung).

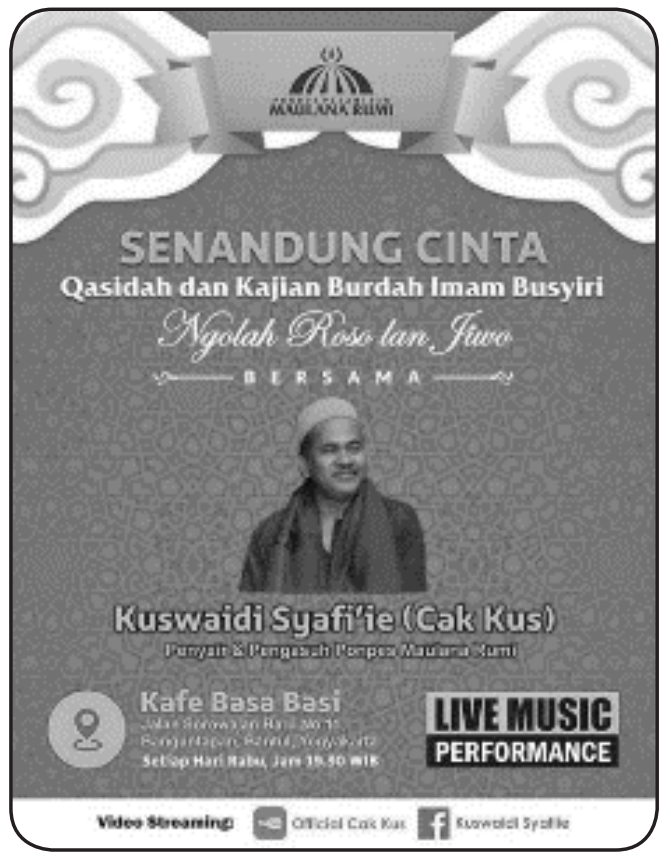

Gambar 2 


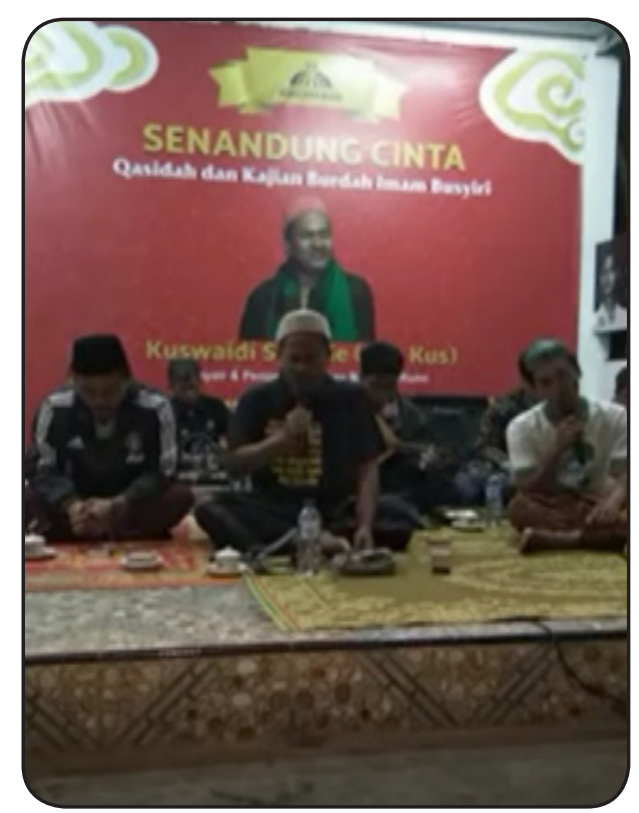

Gambar. 3

Sebelah kiri memakai baju/jaket hitam Pak Edy (pemilik warung kopi), di tengah memakai kaos dan peci putih Cak Kus, sebelah kanan dan belakang adalah tim dari "Majelis Sholawat \& Tasawuf" Cak Kus

Berlangsungnya acara ini merupakan fenomena keagamaan yang menarik untuk dicermati lebih dalam. Penulis belum bisa memastikan apakah ini ada kaitannya dengan strategi bisnis atau tidak, mengingat warung kopi ini baru berdiri pada akhir 2017. Jika ada, penulis cenderung masih belum bisa memahaminya secara baik. Pasalnya, setiap kali acara hendak berlangsung, para pengopi dan pengunjung justru sebagian ada yang meninggalkan warung, atau beberapa memilih pergi ke ruangan terbuka yang difasilitasi oleh pengelola warung. Ruangan yang di dalam cenderung banyak yang kosong atau longgar. Memang, kelonggaran ini tidak berlangsung dengan stabil di setiap acara, namun dibandingkan dengan kegiatan lain -seperti pentas musik, bedah buku, atau pada saat dialog bersama Sujiwo Tejo (Senin, 29 Januari 2018), Ulil Absar Abdalla (Minggu, 4 Februari 2018), dan lainnya-, kelonggaran ini akan terlihat dengan jelas. Artinya, jika ini merupakan salah satu strategi bisnis, tentu ini sesuatu yang tidak menguntungkan bagi pemilik warung kopi itu sendiri.

Ada dua faktor mengapa pengajian sufi Senandung Cinta menjadi salah satu kegiatan rutin di Warung Kopi Basa Basi. Pertama, ngalap berkah atau mencari berkah kepada sufi masyhur di Yogyakarta (jawaban atas pertanyaan penulis kepada manajer Basa Basi, Dani, 20 Februari 2018). Kedua, bisa dikatakan, ada kontinuitas relasi guru-murid yang terjalin antara Pak Edy, pemilik warung, dengan Cak Kus. Relasi Pak Edy dengan Cak Kus terbilang sudah lama terjalin sebelum berdirinya warung kopi Basa Basi (obrolan santai penulis dengan murid Cak Kus, Fajri Andika, 15 Maret 2018). Dua faktor ini hingga saat ini masih menjadi jawaban penulis atas pertanyaan mengapa pengajian sufi diselenggarakan di Basa Basi. Dalam kerangka pandang saat ini, fenomena ini termasuk bagian dari rangkaian kontinuitas kebangkitan Islam (Islamic revival) yang sudah berlangsung sejak akhir abad 20 .

Pengajian sufi yang dipimpin oleh Cak Kus di warung kopi tidaklah berlangsung tanpa elemen-elemen penting lainnya. Selain ditemani kopi dan rokok, ada lagu dan musik disertai tarian sufi yang diperankan oleh dua orang, satu perempuan dan satu lelaki (awalnya satu orang lelaki). Lagu yang dibawakan tidaklah tetap dan selalu bergantiganti. Lagu-lagu shalawatan (pujian kepada Nabi Muhammad Saw) memang lebih dominan akan tetapi lagu-lagu daerah terkadang juga tidak lupa untuk dibawakan, seperti lagu khas Melayu yang berjudul "Laksmana Raja di Laut". Model semacam ini memang tidak dapat dipungkiri dapat menimbulkan antusias banyak orang. Bukan hanya para jama'ah yang duduk di bawah berada tepat di depan panggung, para pengunjung dan pengopi yang duduk di atas kursi juga banyak yang mengapresiasi variasi lagu yang dimainkan. Ini amat terlihat jelas 
seperti pada saat vokalisnya Cak Kus (seorang wanita) menarik nafas panjang dan menyanyikan lirik pertama dari lagu "Laksmana...", semua pengunjung dan pengopi langsung memberikan applause (tepuk tangan) dengan meriah bahkan meminta tambahan lagu lagi setelah lirik lagu usai dinyanyikan.

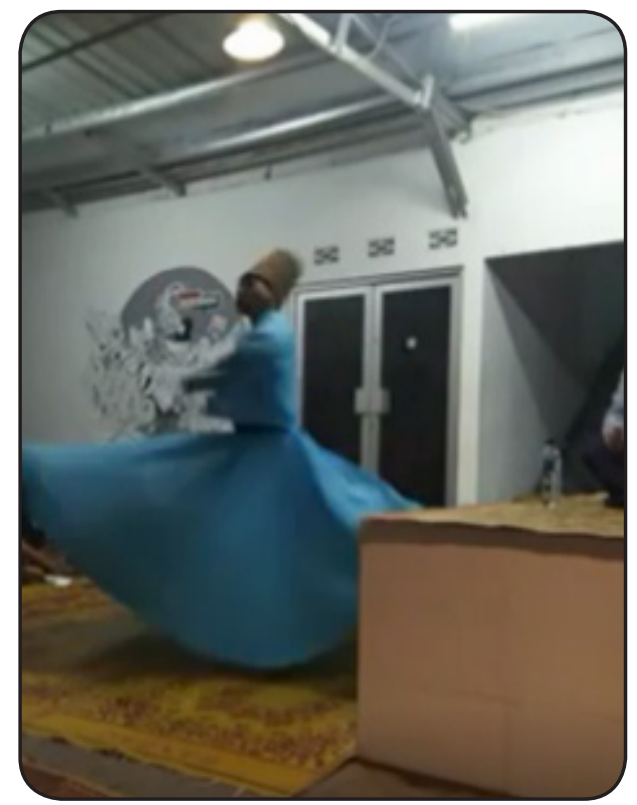

Gambar. 4 Tari Sufi Sema

Gambar diambil dari sebelah barat dan sebelum tari sufinya diperankan oleh dua orang.

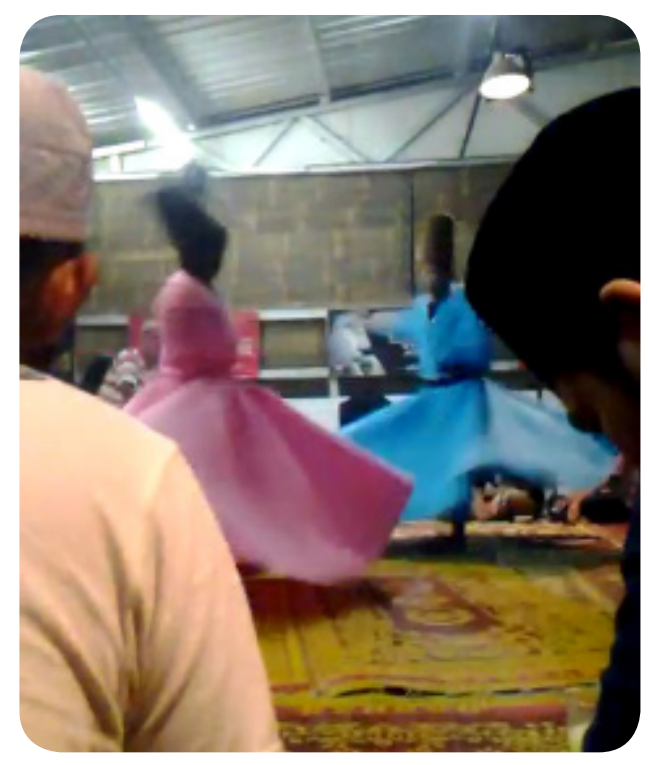

Gambar. 5 Tari Sufi Sema

Gambar diambil dari sebelah utara panggung. Pakaian warna pink merupakan penari wanita dan pakaian warna biru laut merupakan penari lelaki.
Lagu, musik dan tarian sufi serta doa-doa dan pembacaan Barzanji yang selalu ditampilkan dalam setiap berlangsungnya acara merupakan elemen-elemen yang saling berkaitan satu sama lain, di samping juga menjadi aspek integral dalam tradisi sufisme. Beberapa komponen yang ditampilkan oleh Cak Kus dan timnya tersebut secara jelas mengacu pada tradisi sufisme Jalaluddin Rumi (1207-1273 M), seorang sufi besar kelahiran Balkh (atau Afghanistan sekarang) dan meninggal di Konya, Turki. Tradisi ini biasa disebut dengan tari Sema, Sama', atau Whirling Dervishes (uraian lebih mendalam bisa di baca dalam Lewisohn, 1997). Berkaitan dengan tari Sema, ada banyak tafsir mengenai makna dari tarian ini (lihat Barber, 1986), namun penulis tidak akan menguraikan secara mendalam di tulisan ini. Makna tari Sema itu sendiri secara sederhana, menurut Kholis, penari sufi (lihat gambar. 4 pakaian warna biru laut) dalam Senandung Cinta, merupakan tarian kesedihan Maulana Rumi (penjelasan Kholis kepada penulis pada 20 April 2018).

Selain model performa Cak Kus yang terdiri dari doa-doa, lagu, musik dan tari sufi, ada beberapa parameter lain untuk mengatakan bahwa dakwah Cak Kus berorientasi sufisme Jalal alDin Rumi. Pertama, paling mudah bisa dilihat kembali pada Gambar. 1 dan Gambar. 2, yang secara jelas menyebut nama "Maulana Rumi". Kedua, lembaga pendidikan yang didirikan sekaligus diasuh oleh Cak Kus secara jelas memakai "Maulana Rumi" sebagai nama pesantrennya. Dua hal ini sebenarnya sudah cukup untuk mengatakan begitu besarnya warna pemikiran sufisme Rumi dalam cara pandang Cak Kus.

Namun, agar lebih jelas, ada hal penting lain yang bisa disimak dalam setiap sesi dakwah Cak Kus di warung kopi. Kerangka pikir Rumi sering menjadi basis Cak Kus untuk menjelaskan berbagai 
persoalan kehidupan hingga doktrin dan praktek sufisme dalam beribadah. Kenyataan ini nampak jelas terlihat pada frekuensi kata "cinta" yang digunakan oleh Cak Kus. Misalnya,

"Sesuatu yang paling mahal di akhir zaman ini adalah cinta. Cinta sudah tergantikan oleh berbagai hasrat yang hina dan gemuruhnya nafsu. Keinginan dan keserakahan semakin mengikis sifat-sifat ke-Ilahian manusia paling mendasar. Karenanya, timbul berbagai persoalan kehidupan. Andaikan cinta bisa didudukan dalam diri manusia, satu-satunya sikap yang bisa disebarkan untuk menyikapi perbedaan adalah toleransi, kasih sayang, dan mau memahami berbagai macam perbedaan." (salah satu bagian dari konten ceramah Cak Kus pada 31 Januari 2018).

"Cinta itu lebih kuasa dibandingkan dengan manusia. Seperti yang kita ketahui, cinta adalah salah satu sifat penting dari Tuhan. Tuhan menciptakan dunia ini murni dari dasar cinta. Karenanya, tak mungkin Tuhan memiliki pamrih kepada semua makhluknya. Atas dasar ini, orangorang suci juga tidak memiliki pamrih kepada siapa pun, bahkan kepada Tuhannya. Pamrih mereka dihilangkan dalam ibadahnya, ibadahnya digerakkan bukan ingin mendapatkan surganya bukan pula karena takut nerakanya, namun murni karena digerakkan oleh kobaran cinta belaka." (salah satu bagian dari konten ceramah Cak Kus pada 7 Februari 2018).

"Orang yang jatuh cinta, itu biasanya ketika sudah masuk ke bagian yang paling dalam, itu yang dipakai hanyalah kacamata kuda, yaitu keterfokusan dan tidak pernah terpecah ke manamana. Selain kekasih bukanlah siapasiapa, selain kekasih tidak memiliki nilai apa-apa. Ini celakanya kita ketika tidak mengalami transendensi.
Sebenarnya cinta kepada makhluk itu bisa menjadi pembelajaran untuk kemudian mengalami pendakian untuk lebih tinggi, tapi ketika tidak pernah mengalami pendakian, cinta itu menjadi bermasalah bagi dirinya sendiri. Yaitu menjadi sebuah gang buntu yang akan ditabrak berkali-kali sehingga nasib si pecinta ini benjol sana sini karena sudah tidak ada fertilasi yang menuju kepada cakrawala ke-Ilahian. Itulah berbahayanya cinta ketika sudah tidak ada fertilasi kerohanian." (salah satu bagian dari konten Cak Kus pada 14 Februari 2018)

Beberapa petikan potongan ceramah di atas penulis ambil dari tiga acara yang berurutan dari akhir Januari hingga pertengahan Februari. Masih cukup banyak yang perlu disajikan, namun tidak mungkin semua penulis paparkan di sini. Setidaknya, tiga kutipan di atas sudah memunculkan nuansa sufisme Rumi yang kental sekali dalam pemikiran Cak Kus. Formasi sosial moral dalam masyarakat yang plural tentu sangat memerlukan adanya proliferasi doktrin dan praktek sufisme semacam ini. Penekanan doktrin Cak Kus tentang cinta, bukan hanya cinta kepada makhluk melainkan juga kepada Tuhan, memiliki pengaruh yang signifikan di masyarakat. Situasi semacam ini, bahkan, bisa diamati secara langsung pada saat proses berlangsungnya dakwah sufisme itu sendiri. Proposisi yang bisa diajukan dari hal ini adalah, bagaimanapun, ketika propagator lebih banyak berbicara tentang cara membangun kehidupan yang toleran dan penuh kasih sayang, baik dalam konteks sosial maupun spiritual, siapa pun yang melihat dan mendengarnya, kendatipun berbeda agama dan kepercayaan, tentu secara psikologis akan terpengaruh oleh konten dakwah yang disampaikan. Beranjak dari hal ini, penulis akan memaparkan kategori masyarakat yang ada di warung kopi di bagian berikutnya. Hal ini penting 
sebagai penopang dan pembuktian atas proposisi yang sudah diajukan sebelumnya.

\section{Kategori Masyarakat Warung Kopi: Pengikut, Pengopi, dan Pengunjung}

Karakteristik warung kopi yang terbuka dan bebas bagi semua kelas dan struktur sosial -meski tidak semuanya, pada akhirnya berkonsekuensi pada pluralitas masyarakat di warung kopi itu sendiri. Secara struktural, masyarakat di warung kopi, khususnya yang menjadi subjek bahasan dalam tulisan ini, terdiri dari berbagai kelas, dari mahasiswa hingga dosen, penulis hingga peneliti, dari kelas menengah ke bawah hingga kelas menengah ke atas. Namun, perlu dipahami bahwa bagian dari tulisan ini tidak membahas mengenai berbagai kategori kelas sosial tersebut. Bagian ini hanya akan memetakan kategori masyarakat pada saat proses propagasi sufisme sedang berlangsung, yaitu Pengikut atau Jama'ah "Senandung Cinta", Pengopi, dan Pengunjung. Dalam tiga kategori ini, tidak dapat dibatasi secara spesifik karena adanya percampuran kelas di dalamnya. Berikut penulis paparkan tiga kategori itu berdasarkan fenomena yang penulis tangkap di lapangan.

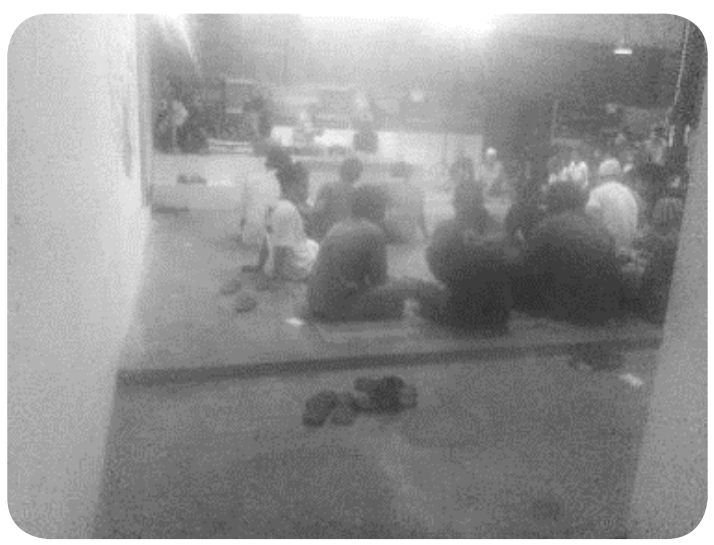

Gambar. 6

Suasana khusyuk Jama'ah mendengar ceramah Cak Kus
Pertama, pengikut atau jama'ah "Senandung Cinta". Kelompok pertama ini terdiri dari anggota masyarakat yang, baik sengaja atau tidak, berada di Basa Basi dan melihat, mendengar, dan memperhatikan secara seksama apa yang disampaikan oleh Cak Kus. Untuk melakukan pemetaan atas kategori yang pertama ini, tidak terlalu sulit. Biasanya posisi mereka berada di bagian paling depan, duduk di atas tikar dan tidak duduk di atas kursi.

Kedua, pengopi. Kelompok kedua ini terdiri dari anggota masyarakat yang memiliki kebiasaan minum kopi setiap harinya dan sering kali dilakukan di Basa Basi. Kategori yang kedua ini, meskipun pengajian "Senandung Cinta" sedang berlangsung, mereka tetap menikmati kopi bersama temantemannya. Pada umumnya, mereka duduk di atas kursi bersama para pengunjung lainnya. Dalam kategori pengopi ini, terdapat variasi akseptasi di antara mereka di saat berlangsungnya "Senandung Cinta". Meskipun mereka tidak bergabung dan mendengarkan seksama apa yang disampaikan oleh Cak Kus, mereka terkadang memberikan respons menarik pada momen-momen tertentu, seperti pada saat prosesi ritual Maulid Nabi, sebagian mereka banyak yang ikut bershalawat dan berdiri untuk menghormati tahapan ritual Mahal alQiyam.

Ketiga, pengunjung. Kelompok ini adalah pengunjung warung Basa Basi yang bukan rutin harian. Dalam hal ini, pengunjung yang bukan rutin terdiri dari pengunjung baru, pengunjung mingguan, atau pengunjung bulanan. Mereka semua belum tentu meminum kopi pada saat berkunjung ke Basa Basi. Menu-menu lain yang disediakan oleh warung -seperti juz buah, minuman jahe, es susu, makanan ringan, kentang goreng, jamur, dan sebagainya- merupakan banyak pilihan yang diharapkan sesuai 
dengan selera mereka. Umumnya, mereka tidak tahu akan adanya pengajian "Senandung Cinta". Mereka tahunya pada saat acara rutinan itu berlangsung di tengah menikmati menu-menu yang telah dipesannya.

Ketiga kategori itu merupakan pemetaan sederhana dari penulis untuk melakukan analisis lebih lanjut. Adanya tiga kategori itu menunjukkan bahwa tidak semua masyarakat warung kopi di Basa Basi mengikuti dakwah "Senandung Cinta", meskipun semuanya berada dalam satu warung yang terbagi menjadi tiga lokasi: ruangan beratap atau ruangan dalam, ruangan terbuka di depan warung kopi, dan ruangan terbuka di samping warung kopi.

\section{Lanskap Harmoni Masyarakat Warung Kopi}

Sebelum masuk pada uraian tentang lanskap harmoni, perlu kiranya mengetahui secara lebih spesifik bahwa ketiga kategori masyarakat warung kopi seperti diuraikan di atas, tidak semuanya memiliki latar belakang yang sama. Dalam kategori pertama, kedua, dan ketiga, masing-masing memiliki identitas yang berbeda: ada yang dari kalangan mahasiswa, baik S1, S2, bahkan S3; ada pula yang berasal dari golongan dosen, seperti dosen dari IAIN Surakarta, Juma panggilan akrabnya; demikian pula dari kelas menengah ke bawah hingga kelas menengah atas. Kelas menengah ke bawah bukanlah mengada-ada dari penulis, karena meskipun uang mereka pas-pasan (biasanya dari kalangan mahasiswa), mereka tetap bisa melakukan aktivitas ngopi bersama teman-temannya dengan cara menukar lima nota kopi yang bisa dikumpulkan dari para pengunjung lain (program 5 nota, gratis 1 kopi).

Di samping latar belakang kelas sosial, tiga kategori di atas juga memiliki latar belakang dan pemahaman keagamaan yang berbeda, tergantung tingkat pendidikan, pemikiran, serta organisasi keagamaan yang diikutinya di luar warung kopi. Tentu masih banyak diversitas latar belakang yang tidak bisa penulis gambarkan semuanya. Bukan berarti tidak ada lagi, ini karena data yang penulis dapatkan baru sebatas ini.

Beranjak dari uraian singkat di atas, akan semakin mudah dipahami bagaimana lanskap harmoni yang penulis maksud di sini. Masyarakat warung kopi dengan variasi latar belakang sosial dan keagamaan, memberikan keunikan tersendiri dalam menampilkan panorama harmoni di warung kopi. Kondisi ini semakin nampak jelas ketika acara "Senandung Cinta" sedang berlangsung. Beberapa elemen dalam kegiatan dakwah tersebut, dalam sejarahnya bahkan hingga saat ini, pada kenyataannya tidak semuanya diterima penuh oleh semua kalangan, seperti tradisi maulid Nabi dan pembacaan shalawat yang masih berada dalam posisi penolakan oleh sebagian kelompok muslim. Salah satu parameter paling mudah untuk melihat perbedaan ini adalah bagaimana sikap mereka ketika prosesi ritual maulid Nabi sampai pada tahap Mahal al-Qiyam, mereka berdiri atau tidak. Dari sini, kita dapat melihat bagaimana respons yang dilakukan oleh masyarakat warung kopi pada saat berlangsungnya pengajian.

Sikap akseptasi terhadap kegiatan rutin propagasi sufisme nampak jelas ditampilkan oleh masyarakat warung kopi. Akseptasi di antara pengikut atau jama'ah, pengopi dan pengunjung, masing-masing menampilkan corak yang berbeda. Corak ini bisa dilihat dari cara mereka bersikap pada saat pengajian berlangsung, masing-masing melakukan aktivitasnya dalam satu ruang tanpa ada yang merasa terganggu satu sama lainnya. Bahkan, beberapa pengopi dan pengunjung -terlepas dari afiliasi keagamaan mereka di luar warung kopi-

\begin{tabular}{l|l} 
Jurnal Multikultural \& Multireligius Vol. 17 & No. 1
\end{tabular} 
ada yang menampilkan corak lebih dari sekadar penerimaan, beberapa di antara mereka bahkan memberi penghormatan yang luar biasa. Misalnya, ikut berdiri pada saat ritual Maulid Nabi sampai

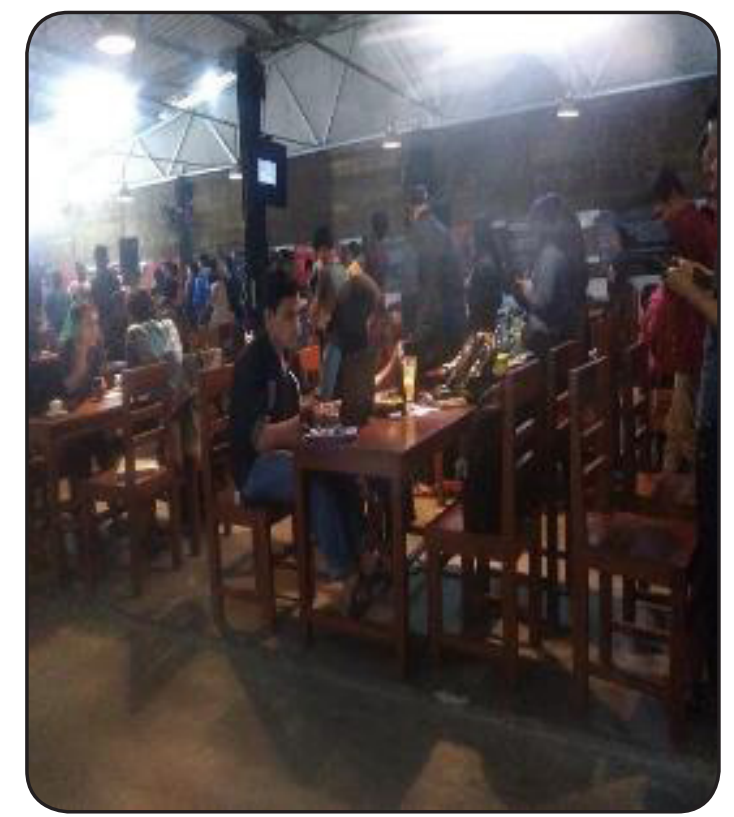

pada tahap Mahal al-Qiyam, meskipun beberapa dari mereka yang melakukan itu masih juga melanjutkan aktivitasnya, seperti berdiri sambil main gadget, atau berbincang dengan teman lainnya.

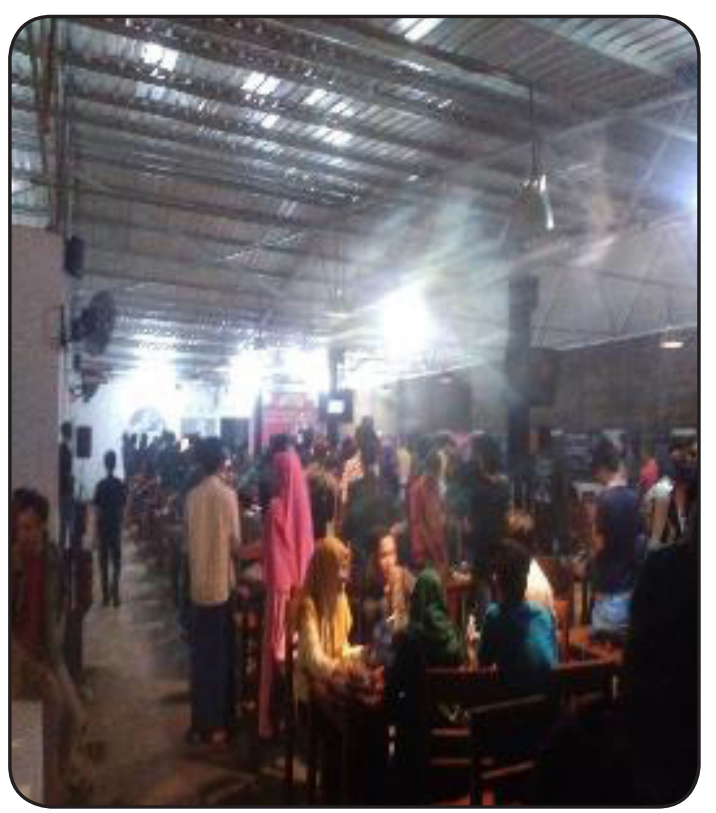

Gambar. 7 dan 8

Ritual mahal al-qiyam yang mendapat penerimaan dan penghormatan dari pengopi dan pengunjung. Penerimaan terlihat dalam bentuk tidak ada perasaan terganggu dari mereka, masing-masing masih melanjutkan aktivitasnya (terlihat pada yang duduk). Sementara penghormatan terlihat dalam bentuk sikap mereka yang ikut berdiri, meskipun aktivitasnya masih tetap berlanjut, seperti main gadget (gambar. 7).

Tentu saja, fenomena ini bisa dikatakan sebagai salah satu dampak dari strategi dakwah yang dilakukan oleh Cak Kus. Meskipun secara resmi di dukung oleh pemilik warung kopi, tetap saja tidak ada paksaan dari pimpinan "Senandung Cinta", Cak Kus, kepada masyarakat warung kopi untuk mengikuti pengajiannya. Selain itu, doktrin dan praktek sufisme yang di diseminasikan oleh Cak Kus juga tak kalah pentingnya. Elaborasi sufisme Cak Kus dengan berbagai persoalan sosial di masyarakat, terutama persoalan jomblo yang menjadi persoalan umum di kalangan masyarakat warung kopi, baik jama'ah, pengopi, maupun pengunjung, menimbulkan banyak simpati di semua anggota masyarakat yang hadir di warung kopi. Dari situasi ini, bisa ditarik pemahaman bahwa ada relasi signifikan antara sufisme dengan pembentukan formasi sosial moral di masyarakat.

Kendati fenomena ini terjadi di warung kopi, bahkan hanya terbatas pada satu warung kopi yang menjadi subjek kajian tulisan ini, namun tetap saja ini merupakan modal penting bagi masyarakat Indonesia. Modal penting untuk membangun masyarakat yang toleran dan harmoni bagi masa depan bangsa, karena sebagian besar dari 
masyarakat warung kopi pada umumnya adalah generasi muda. Di sisi lain, warung kopi kini juga semakin menjadi ruang yang multifungsi, bukan hanya sebagai ruang berkumpul atau bercerita, minum kopi, atau membentuk opini publik, melainkan juga dapat berfungsi sebagai ruang sekaligus media dakwah sufisme.

\section{SIMPULAN}

"Senandung Cinta" merupakan tema kegiatan rutin Cak Kus di warung kopi Basa Basi. Adanya fenomena ini memberikan tambahan beberapa poin penting dalam khazanah studi tasawuf selama ini. Pertama, jangkauan sufisme yang dipandang mampu menjangkau berbagai sektor ruang publik sejak kebangkitan Islam akhir abad 20, ternyata juga mampu merambah di area generasi muda, yakni warung kopi, yang dalam sejarah Islam tidak selalu stabil dan aman. Dari fenomena ini pula, kontinuitas relasi sufi dan kopi bisa dikatakan semakin melebar dan kompleks, bukan hanya antara sufi, sufisme, dan kopi, melainkan juga ke tempat penjualan kopi itu sendiri. Dapat dikatakan, warung kopi kini menjadi salah satu ruang sekaligus media potensial untuk propagasi sufisme.

Kedua, hipotesa tentang signifikansi sufisme dalam formasi sosial danmoralitas publik bisa dibilang masih kokoh hingga saat ini. Relasi langsung antara kegiatan dakwah sufisme dengan objek propagasi yang terdiri dari berbagai kategori dan kelas sosial di warung kopi, merupakan lanskap yang menarik sekaligus menguatkan hipotesis tersebut. Menarik, karena fenomena akseptasi di antara Jama'ah, Pengopi, dan Pengunjung pada saat pengajian berlangsung menampilkan corak dan karakteristik yang unik. Tidak sebatas hanya menerima dan tidak merasa terganggu atas kehadiran pengajian sufisme, beberapa pengunjung dan pengopi bahkan ada yang memberi penghormatan atas berlangsungnya acara tersebut, seperti ikut berdiri pada saat prosesi mahal al-qiyam dalam ritual Maulid Nabi. Cara menyikapi keragaman dan perbedaan nampak jelas ditampilkan oleh masyarakat warung kopi pada saat pengajian berlangsung.

Dua poin penting ini bisa menjadi perhatian lebih lanjut dalam upaya membangun masyarakat yang harmoni dan toleran. Fenomena-fenomena keagamaan seperti yang terjadi di warung merupakan salah satu modal penting yang perlu diperhatikan dan dikelola secara lebih baik oleh masyarakat, juga pemerintah. Apa yang ditampilkan oleh warung kopi Basa Basi bisa menjadi salah satu model dalam pembentukan formasi sosial moral dan pengembangan ekonomi masyarakat Islam secara bersamaan.

\section{UCAPAN TERIMA KASIH}

Penulis mengucapkan terima kasih kepada beberapa dosen di Pascasarjana UIN Sunan Kalijaga, terutama kepada Bapak Najib Kailani P.hD, Dr. Munirul Ichwan, dan Dr. Sunarwoto, yang banyak sekali memberi masukan, saran dan asupan pengetahuan baru terkait metode penelitian dan penulisan ilmiah lintas disiplin selama perkuliahan di Pascasarjana. Terima kasih juga penulis haturkan kepada editor, beberapa pembaca, dan reviewer yang telah memberikan kritik dan masukan untuk memperbaiki tulisan ini. Tidak lupa, terima kasih juga penulis tujukan kepada Pengelola Jurnal Harmoni yang telah berkenan menerbitkannya pada edisi kali ini. Penulis juga mengucapkan banyak terima kasih kepada pihak Manajer Warung/Kafe Basa Basi yang telah memberi ruang cukup lebar untuk penulis selama penelitian. 


\section{DAFTAR ACUAN}

Sumber Primer (Lapangan)

Sumber primer ini merupakan hasil dari pengamatan penulis setiap harinya dari mulai awal Januari 2018 hingga masih berlangsung saat ini, tepatnya di bulan April 2018. Karenanya, penulis tidak mungkin menjelaskan secara detail semua waktunya. Beberapa yang secara jelas digunakan dalam tulisan ini adalah:

Obrolan santai dengan Manajer Basa-Basi, Dani.

Obrolan santai dengan Kholis, Penari Sufi di "Senandung Cinta".

Obrolan santai dengan Fajri Andika, salah satu Jama'ah "Senandung Cinta".

Foto-Foto dan Pamflet.

Rekaman Video.

Catatan Tulis Tangan.

Obrolan acak dengan semua pengopi dan pengunjung.

Buku, Disertasi, dan Jurnal

Bano, S., Sohail, M., \& Hussain, S. S. (2015). Curbing Extremism through Sufism: A South Asian Perspective. South Asian Studies: A Research Journal of South Asian Studies, 30 (1).

Barber, X. T. (1986). Four Interpretations of Mevlevi Dervish Dance, 1920-1929. Dance Chronicle, 9 (3).

Beck, H. L. (2014). The Contested State of Sufism in Islamic Modernism: The Case of the Muhammadiyah Movement in Twentieth-Century Indonesia. Journal of Sufi Studies, 3.

Bruinessen, M. van. (1994). The Origins and Development of Sufi Orders (Tarekat) in Southeast Asia. Studia Islamika, 1(1).

Bruinessen, M. van. (2009). Sufism, 'Popular' Islam and the Encounter with Modernity. In M. K. Masud, A. Salvatore, \& M. van Bruinessen (Eds.), Islam and Modernity: Key Issues and Debates. Edinburgh: Edinburgh University Press.

Fotić, A. (2011). The Introduction of Coffee and Tobacco to the Mid-West Balkans. Acta Orientalia Academiae Scientiarum Hungaricae, 64 (1).

Heck, P. L. (2006). Mysticism as Morality: The Case of Sufism. The Journal of Religious Ethics, 34(2).

Howell, J. D. (2001). Sufism and the Indonesian Islamic Revival. The Journal of Asian Studies, 60(3).

Howell, J. D. (2007). Modernity and Islamic Spirituality in Indonesia's New Sufi Networks. In M. van Bruinessen \& J. D. Howell (Eds.), Sufism and The Modern in Islam. London: I.B. Tauris \& Co. Ltd.

Howell, J. D. (2010). Indonesia's Salafist Sufis. Modern Asian Studies, 44 (5). 
Huda, S. (2017). Sufisme Dakwah Era Kontemporer: Kajian atas Pemikiran dan Praksis M. Fethullah Gülen. UIN Sunan Ampel, Surabaya.

Ichwan, M. N. (2016). Neo-Sufism, Shariatism, and Ulama Politics: Abuya Syhaykh Amran Waly and the Tauhid-Tasawuf Movement in Aceh. In K. van Dijk \& N. J. G. Kaptein (Eds.), Islam, Politics and Change: The Indonesian Experience after the Fall of Suharto. Leiden: Leiden University Press.

Islam, M. T., De Alencar, M. V. O. B., Da Mata. Ana Maria Oliveira Ferreira, Paz, M. F. C. J., Matos, L. A., Sousa, J. M. de C. E., \& Melo-Cavalcante, A. A. de C. (2016). Coffee: A Health Fuel-blot Popular Drinking. International Journal of Pharmacy and Pharmaceutical Sciences, 8 (5).

Johns, A. H. (1995). Sufism in Southeast Asia: Reflections and Reconsiderations. Journal of Southeast Asian Studies, 26 (1).

Jones, A. H. (1961). Sufism as a Category in Indonesian Literature and History. Journal of Southeast Asian History, 2 (2).

Laffan, M. (2007). National Crisis and the Representations of Traditional Sufism in Indonesia: The Periodicals Salafy and Sufi. In M. van Bruinessen \& J. D. Howell (Eds.), Sufism and The Modern in Islam. London and New York: I.B. Tauris \& Co. Ltd.

Lewisohn, L. (1997). The Sacred Music of Islam: Samā' in the Persian Sufi Tradition. British Journal of Ethnomusicology, 6.

Machmudi, Y. (2006). Islamising Indonesia: The Rise of Jemaah Tarbiyah and the Prosperous Justice Party (PKS). The Australian National University, Canberra.

Makhasin, L. (2015). The Politics of Contending Piety: Naqshabandi-Haqqani Sufi Movement and the Struggle for Islamic Activism in Contemporary Indonesia. The Australian National University, Canberra.

Makhasin, L. (2016). Urban Sufism, Media and Religious Change in Indonesia. Ijtimā’ iyya: Journal of Muslim Society Research, 1 (1).

Mas'ud, A. (2011). Dinamika Sufisme Jawa: Studi tentang Pemikiran Tasawuf KH. Saleh Darat Semarang dalam Kitab Minhaj al-Atqiya'. UIN Sunan Ampel, Surabaya.

Ni'am, S. (2015). Merawat Keberagamaan di Balik Perdebatan Kopi dan Rokok: Kajian atas Kitab Irshad al-Ikhwan li Bayani Ahkami Shurb al-Qahwah wa al-Dukhan, K.H. Ihsan Jampes Kediri. Jurnal Lektur Keagamaan, 13 (2).

Rabasa, A., Benard, C., Schwartz, L. H., \& Sickle, P. (2007). Building Moderate Muslim Networks. Santa Monica: RAND Corporation.

Sarr, E. (2016). The Ritual of Slawatan and Neo-Sufism. QUEST: Studies on Religion E Culture in Asia, 1.

Siradj, S. A. (2013). Tasawuf sebagai Basis Tasamuh: Dari Social Capital Menuju Masyarakat Moderat. Al-Tahrir, 13 (1).

Stern, T. N. (1969). Coffee Houses May Stir Intellectual Activity. Improving College and University Teaching, 17 (3).

Topik, S. (2009). Coffee as a Social Drug. Cultural Critique, 71(Winter), 81-106. 
Woodward, M., Umar, M. S., Rohmaniyah, I., \& Yahya, M. (2013). Salafi Violence and Sufi Tolerance? Rethinking Conventional Wisdom. Perspectives on Terrorism, 7 (6).

Zamhari, A. (2010). Rituals of Islamic Spirituality: A Study of Majlis Dhikr Groups in East Java. Canberra: ANU E Press.

Zamhari, A. (2013). Socio-Structural Innovations in Indonesia's Urban Sufism: The Case Study of the Majelis Dzikir and Shalawat Nurul Mustafa. Journal of Indonesian Islam, 7 (1).

Zamhari, A., \& Howell, J. D. (2012). Taking Sufism to the Streets: Majelis Zikir and Majelis Salawat as New Venues for Popular Islamic Piety in Indonesia. Review of Indonesian and Malaysian Affairs, 46 (2). 